\title{
Arsenic Contamination in Water from Selected Boreholes in Nairobi City County, Kenya
}

\author{
Alice S. Kiplangat, Henry Mwangi, Sauda Swaleh and Wilson M. Njue*
}

\section{ABSTRACT}

Arsenic is a metalloid, which may be found in surface water, ground water, plants and rocks. In high concentrations, its compounds are considered to be genotoxic and carcinogenic. Its levels in drinking water must be regularly monitored and controlled. The objective of study was to determine the concentration of arsenic in water with reference to WHO limits from selected boreholes in Nairobi County, Kenya. Water was randomly sampled from a total of 63 boreholes in five zones (Central, Eastern, Northern, Western and Southern) during dry and wet season. The arsenic was analyzed by Hydride Generation Atomic Absorption Spectrometer (HG-AAS). The results showed that the arsenic content in borehole water during dry season ranged between $0.00455 \pm 0.0022$ and $0.01007 \pm 0.006$ and in the range of $0.002057 \pm 0.0008-0.00744 \pm 0.0051 \mathrm{mg} / \mathrm{L}$ during the wet season. There was significant difference $(\mathrm{P}<0.05)$ in arsenic content in borehole water samples in Central zone compared to the other zones. During the dry season, arsenic content in water from ten boreholes $(16 \%)$ and four boreholes $(6 \%)$ during wet season was found to be above the WHO recommended limit of $0.01 \mathrm{mg} / \mathrm{L}$. The calculated contamination factor for the borehole water ranged from slightly arsenic contaminated in Central zone to very slightly contaminated in the other zones during dry season. During the wet season, the borehole water in all the five zones were very slightly contaminated with arsenic. The pollution index showed that the boreholes in all the five zones during both wet and dry seasons were not polluted with arsenic. Steps should be taken to monitor and treat borehole water for domestic purposes in order to mitigate the effect on human health due to arsenic contamination.

Keywords: Arsenic, Borehole water, Contamination factor, Pollution index.

\section{INTRODUCTION}

There are numerous studies around the world on determination of levels of arsenic (As) in water from boreholes and surface water. Many scientists have repeatedly expressed concern about the problem of arsenic pollution [1]. Arsenic enriched minerals have been the primary source of arsenic in the environment. Anthropogenic activities in agriculture (pesticides, herbicides, fertilizers, additives to livestock feed for poultry), mining and combustion of fossil fuels have also led to the introduction of As to the environment [2]. Arsenic occurs naturally in organic and inorganic forms [4], [3] and in four oxidation states, -3, 0, 3 and 5 [5]. The inorganic forms of arsenic compounds in oxidation states, 3 and 5 are the most toxic [6], [7]. The arsenic species in water that have been reported include monomethylarsonic acid (MMA), dimethylarsinic acid (DMA), arsenate and arsenite (Fig. 1). In oxygenated water and sediments, pentavalent state (arsenate) is thermodynamically more stable [8].
Published Online: March 16, 2021

ISSN: $2684-4478$

DOI : $10.24018 /$ ejchem.2021.2.2.50

\section{Alice S. Kiplangat}

Department of Chemistry, School of Pure and Applied Sciences, Kenyatta University, Nairobi, Kenya.

(e-mail: alicekiplangat247@gmail.com) Henry Mwangi

Department of Chemistry, School of Pure and Applied Sciences, Kenyatta University, Nairobi, Kenya.

(e-mail: mwangi.henry@ku.ac.ke)

Sauda Swaleh

Department of Chemistry, School of Pure and Applied Sciences, Kenyatta University, Nairobi, Kenya.

(e-mail: swaleh.sauda@ku.ac.ke)

Wilson M. Njue*

Department of Chemistry, School of Pure and Applied Sciences, Kenyatta University, Nairobi, Kenya.

(e-mail: wilsonnjue@yahoo.com)

*Corresponding Author<smiles>C[As](C)(=O)O</smiles>

Dimethylarsinic acid Monomethylarsonic acid<smiles>O=[As](O)(O)O</smiles>

Arsenate<smiles>[O-][As](O)(O)O</smiles>

Arsenite

Fig. 1. Chemical structure of arsenic species in water. (source: [8]).

Many people in the world consume drinking water with arsenic concentrations that exceeds the WHO recommended limit of $0.01 \mathrm{mg} / \mathrm{L} \mathrm{[9]}$. The population that has been mostly affected by ground water arsenic poisoning in the world includes those from India, Cambodia and Bangladesh [9][11]. About 6 million and 85 million people were affected by arsenic poisoning of ground water in India and Bangladesh respectively [12]. The concentration of arsenic in over 40 districts in Bangladesh had arsenic in groundwater exceeding 
$0.05 \mathrm{mg} / \mathrm{L}$ [13], [14]. A study done in China registered concentrations of arsenic as high as $1.8 \mathrm{mg} / \mathrm{L}$ while those in Cambodia and Vietnam found concentrations as high as 1.34 $\mathrm{mg} / \mathrm{L}$ [15]. A study conducted in Nigeria found out that Arsenic (As) levels in borehole water ranged $0.05 \pm 0.008$ $0.10 \pm 0.041 \mathrm{mg} / \mathrm{L}$ [16].

Studies have shown that As is carcinogenic to both human and animals. There is strong correlation between infant mortality and maternal exposure to arsenic during pregnancy [17]. Depending on the time of exposure, it can either lead to chronic or acute effect [18]. The effects of acute exposure to arsenic can be noticed immediately after drinking the water and can lead to coma and death while chronic exposure causes lesions as shown in Fig. 2 and can be noticed after a few years later [18].

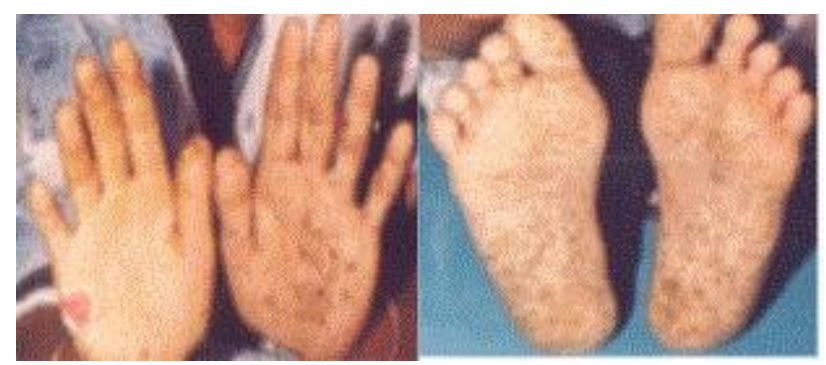

Fig. 2. Skin Lesions on palm and sole [19].

The permitted level of arsenic for drinking water is $0.01 \mathrm{mg} / \mathrm{L}$ as per WHO guidelines [20]. In Kenya, the limit of Arsenic for drinking water permissible by the National Environment Management Authority (NEMA), is $0.01 \mathrm{mg} / \mathrm{L}$ [21].

Kenya has been experiencing severe drought more often than before and this resulted to low levels of surface water, affecting distribution of piped water from rivers to many people across the country. Nairobi County with a population of 4,337,080 has severe water shortage [22]. The daily demand of water in Nairobi County is 740,000 cubic meters against a supply of 540,000 [23]. In order to mitigate this shortfall, the National government has drilled and commissioned more water boreholes to supplement water from rivers and dams [23]. There is therefore, increased concern on the safety and quality of borehole water due to possible contamination with toxic heavy metals such as mercury, cadmium and arsenic. The United States Environmental Protection Agency (US-EPA) has documented techniques of detecting and analyzing the arsenic [24]. These methods include inductively coupled plasma mass spectrometry (ICP-MS), inductively coupled plasma atomic emission spectrometry (ICP-AES), graphite furnace atomic absorption spectrometry (GF-AAS), and Hydride generation atomic absorption spectrometry (HGAAS). HG-AAS has been used to analyze arsenic in water and soil in Kenya [25]. It is commonly used due to its improved detection limit as a result of hydride generator [26]. The method of choice for our study was Hydride Generation Atomic Absorption Spectrometry (HG-AAS).

\section{MAterials AND MethodS}

\section{A. Chemicals}

Chemicals used were of analytical grade. They included concentrated hydrochloric acid, concentrated nitric acid, sodium hydroxide, potassium iodide, sodium borohydride pellets and arsenic trioxide. They were procured from Merck chemicals (Darmstadt, Germany) and Sigma Aldrich (St. Louis, MO).

\section{B. Sample collection}

Sampling was done in Nairobi County, whose map is shown in Figure 3. The County is located at longitudes $36^{\circ}$ $45^{\circ}$ East and latitudes $1^{\circ} 18^{\circ}$ South.

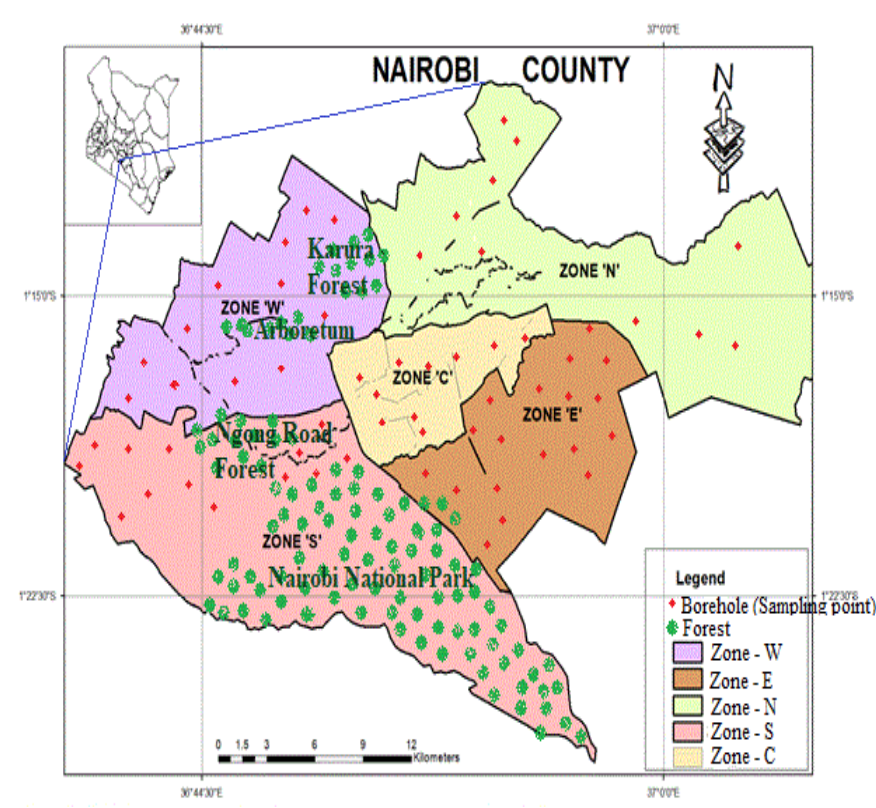

Fig. 3. Map of Nairobi County showing sampling zones (Source: Author, 2020).

The study area was divided into five zones based on their various land uses. The zones comprised of Western (zone $\mathrm{W})$. This zone has agricultural activities and is one of the deep percolations for groundwater in Nairobi. The next zone was Central (zone C). This area is dominated by light and heavy manufacturing industries. Eastern zone (zone E) is on a lower elevation. The Northern zone (zone N) has the sewage treatment plant at Ruai. The Southern zone (zone S) has the largest informal settlement at Kibra with high level of soil and water pollution. The total number of boreholes in Nairobi County is 2,632 [27] The study area was divided into approximately $4 \mathrm{~km}^{2}$ blocks. The study blocks design assumed that the land use of each block was fairly uniform and therefore the borehole picked at random was a representative of the studied block [28]. A total of 63 boreholes were selected for the study. The 189 samples were collected during dry season (January to February, 2020) and 189 samples during wet season (April to May, 2020). Plastic sampling bottles of $50 \mathrm{ml}$ were soaked in dilute nitric acid overnight then rinsed thoroughly with distilled water. At each sampling point, the water from borehole were allowed to run for 2 minutes then sampling bottles rinsed with the water from the borehole before filling it. Water samples were collected in three sets from each site and labeled. The $\mathrm{pH}$ was then measured immediately on site after collection with a digital portable $\mathrm{pH}$ meter. The water samples were collected from each borehole at intervals of two hours, between the hours of 8.00 am to $2.00 \mathrm{pm}$. The samples were then treated with $1 \mathrm{ml} \mathrm{HCl}$ for preservation before being transported to 
the laboratory [29]. The bottles were stored at $4{ }^{\circ} \mathrm{C}$ at Jomo Kenyatta University of Science and Technology research laboratory Kenya.

\section{Preparation of Stock Solution}

Arsenic standard stock solution was prepared daily by dissolving $0.33 \mathrm{~g}$ of arsenic trioxide, $\mathrm{As}_{2} \mathrm{O}_{3}$ (analytical reagent grade) in $25 \mathrm{~mL}$ of deionized distilled water containing $1 \mathrm{~g} \mathrm{NaOH}$. The solution was then acidified with 5 $\mathrm{mL}$ conc. $\mathrm{HNO}_{3}$ and diluted to $250 \mathrm{~mL}$.

\section{Preparation of Standard Solution}

Standard working solutions of $5 \mathrm{mg} / \mathrm{L}, 10 \mathrm{mg} / \mathrm{L}, 15 \mathrm{mg} / \mathrm{L}$, $20 \mathrm{mg} / \mathrm{L}, 25 \mathrm{mg} / \mathrm{L}$, and $30 \mathrm{mg} / \mathrm{L}$ were prepared daily by serial dilution of the stock solution using deionized water. The standards were then read in a HG-AAS and a calibration curve (Fig. 4 ) of a good linearity was obtained $\left(R^{2}=0.9986\right)$.

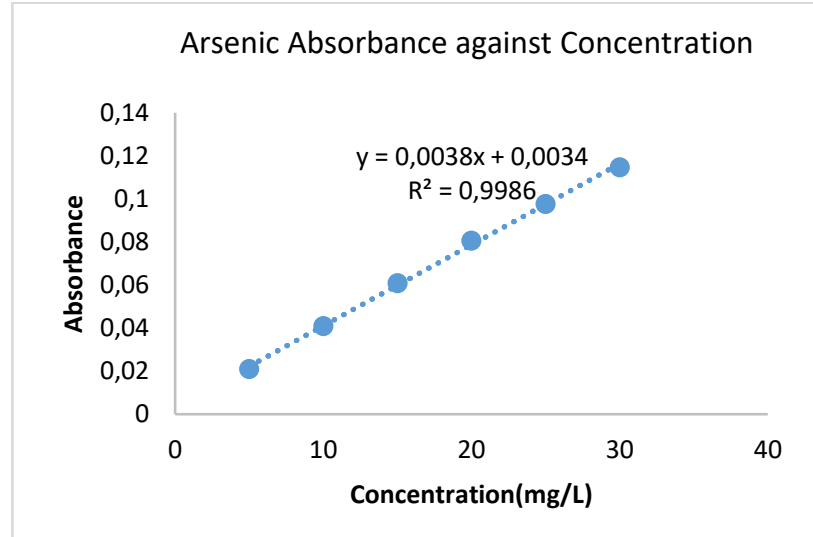

Fig. 4. Calibration curve for Arsenic Standards.

\section{E. Method Validation Procedures}

Accuracy was tested through recovery experiments. In recovery, samples were spiked with arsenic standard then added to a sample in triplicate and extraction procedure followed. The amount of spiked arsenic in water borehole water digest was used to determine percentage recovery using equation below [30].

$\%$ Recovery $=\frac{\text { Spiked sample Concentration-Unspiked Sample Concentration }}{\text { Concentration of the Standard used for Spiking }} \times 100$

The precision of the method was calculated by equation:

$\%$ Relative Standard Deviation $(\mathrm{RSD})=\frac{\text { Standard Deviation }}{\text { Mean }} \times 100$

The calculated values are given in Table I.

TABLE I: PERCENTAGE OF RECOVERIES AND RELATIVE STANDARD

\begin{tabular}{cccc}
\multicolumn{4}{c}{ DEVIATION } \\
\hline Sample & $\begin{array}{c}\text { Recovered } \\
\text { concentration }(\mathrm{mg} / \mathrm{L})\end{array}$ & \% Recovery & \% RSD \\
\hline I & $0.0098 \pm 0.0003$ & 98 & 3.1 \\
II & $0.0146 \pm 0.0002$ & 97 & 1.4 \\
III & $0.0193 \pm 0.0005$ & 97 & 2.6 \\
IV & $0.0238 \pm 0.0006$ & 95 & 2.5 \\
\hline
\end{tabular}

The percentage recoveries obtained were close to $100 \%$ hence the method was accurate for quantification of As levels in the test samples. The \%RSD values were below $5 \%$, an indication of good precision.

\section{F. Statistical Analysis}

The means of arsenic content in water from boreholes were compared between two sets of values using one- way ANOVA by Turkey's HSD test. T- test was used to test whether there were significant differences between the two sets of means. If the calculated t-value is greater than the critical t-value, then the two groups are significantly different at significance level of .05 and vice versa [31]. All the statistical analysis was done with SPSS version 21 software.

\section{G. Contamination Factor}

Contamination factor $(\mathrm{CF})$ provides a measure of the degree of overall contamination in a sampled site [32]. The Contamination factor requires that at least five surficial sediment samples are averaged to produce a mean pollutant concentration which is then compared to a baseline pristine reference level [32], [33].

$$
C F=C m / C b
$$

where,

$\mathrm{Cm}$ - metal concentration;

$\mathrm{Cb}$ - base line/background value.

The World Health Organization (WHO) background value $(\mathrm{Cb})$ for drinking water was used for this work [20].

\section{H. Pollution Index(PI)}

Pollution index (PI) was calculated using the equation given [34].

$$
P I=\frac{C F 1 \times C F 2 \times C F 3 \ldots C F n}{n}
$$

where,

$n$ is the number of metals;

$C F$ is the contamination factor.

The contamination/pollution index values according to Lacatusu [35] are:

$<0.1$ - very slightly contaminated,

$0.10-0.25$ - slightly contaminated,

$0.26-0.5$ - moderately contaminated,

$0.51-0.75$ - severely contaminated,

$0.76-1.00$ is very severely contaminated,

$1.1-2.0$ is slightly polluted,

$2.1-4.0$ is moderately polluted,

4.1-8.0 - severely polluted,

$8.1-16.0$ - very severely polluted and

$>16$ - excessively polluted.

\section{RESUlTS AND DisCUSSION}

The results of water samples analysis for arsenic are shown in Tables II to VI. The arsenic levels in water in boreholes in Central zone (Table II) ranged from $0.0017 \pm 0.0001$ to $0.0219 \pm 0.0008 \mathrm{mg} / \mathrm{L}$ with an overall mean of $0.0101 \pm 0.0065 \mathrm{mg} / \mathrm{L}$ during the dry season and $0.0006 \pm$ 0.0001 to $0.0144 \pm 0.0002 \mathrm{mg} / \mathrm{L}$ with an overall mean of $0.0074 \pm 0.0048 \mathrm{mg} / \mathrm{L}$ during the wet season. The overall mean arsenic content in water in Eastern zone (Table III), Northern zone (Table IV), Southern zone (Table V) and 
Western zone (Table VI) during dry season were $0.0087 \pm 0.0052, \quad 0.0046 \pm 0.0022, \quad 0.0051 \pm 0.0035$ and $0.0047 \pm 0.0024 \mathrm{mg} / \mathrm{L}$ respectively. During the wet season they were $0.0040 \pm 0.0022,0.0021 \pm 0.0008,0.0025 \pm 0.0012$, and $0.0025 \pm 0.0012 \mathrm{mg} / \mathrm{L}$ respectively. A probable explanation of low arsenic concentration in the wet season compared to dry season could be due to rapid movement of water into the aquifer causing water dilution during wet season [36]. Further recharge during the wet season also conveys pollutants into the aquifers, which then concentrate in the dry season hence higher levels. The arsenic concentration in water in boreholes in Central zone was higher than in all the four other zones. This could be attributed to the seepage of industrial effluents or leakage from underground storage of petroleum and chemicals in the zone.

TABLE II: MEAN LEVELS OF ARSENIC IN CENTRAL ZONE WATER

\begin{tabular}{|c|c|c|}
\hline \multicolumn{3}{|c|}{ BOREHOLES } \\
\hline Borehole Code & $\begin{array}{c}\text { Mean }(\mathrm{mg} / \mathrm{L}) \\
\pm \text { Standard Deviation } \\
\text { (Dry Season) }\end{array}$ & $\begin{array}{c}\text { Mean }(\mathrm{mg} / \mathrm{L}) \\
\pm \text { Standard Deviation } \\
\text { (Wet Season) }\end{array}$ \\
\hline C6 & $0.0219 \pm 0.0008$ & $0.0040 \pm 0.0001^{\mathrm{q}}$ \\
\hline $\mathrm{C} 8$ & $0.0186 \pm 0.0002$ & $0.0144 \pm 0.0002$ \\
\hline $\mathrm{C} 7$ & $0.0141 \pm 0.0002^{\mathrm{a}}$ & $0.0130 \pm 0.0002^{\mathrm{n}}$ \\
\hline $\mathrm{C} 4$ & $0.0129 \pm 0.00009^{\mathrm{a}}$ & $0.0093 \pm 0.0001^{\mathrm{m}}$ \\
\hline $\mathrm{C} 10$ & $0.0071 \pm 0.0001^{\mathrm{b}}$ & $0.0084 \pm 0.0001^{\mathrm{m}}$ \\
\hline $\mathrm{C} 5$ & $0.0067 \pm 0.0008^{\mathrm{b}}$ & $0.0013 \pm 0.0004^{\mathrm{r}}$ \\
\hline $\mathrm{C} 2$ & $0.0066 \pm 0.0001^{\mathrm{b}}$ & $0.0016 \pm 0.0001^{\mathrm{r}}$ \\
\hline $\mathrm{C} 9$ & $0.0062 \pm 0.0002 b^{c}$ & $0.0123 \pm 0.0001^{\mathrm{n}}$ \\
\hline $\mathrm{C} 3$ & $0.0049 \pm 0.0001^{\mathrm{c}}$ & $0.0043 \pm 0.0001^{\mathrm{pq}}$ \\
\hline $\mathrm{C} 1$ & $0.0017 \pm 0.0001$ & $0.0054 \pm 0.0001^{\mathrm{p}}$ \\
\hline Overall Mean & $0.0101 \pm 0.0065$ & $0.0074 \pm 0.0048$ \\
\hline Calculated t-value & \multicolumn{2}{|r|}{ 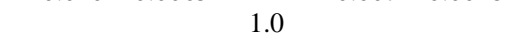 } \\
\hline $\begin{array}{l}\text { Critical t-value } \\
\text { (Tabled t-value) }\end{array}$ & \multicolumn{2}{|c|}{2.101} \\
\hline $\begin{array}{c}\text { Contamination } \\
\text { Factor }\end{array}$ & 1 & 0.74 \\
\hline Pollution Index & 1 & 0.74 \\
\hline
\end{tabular}

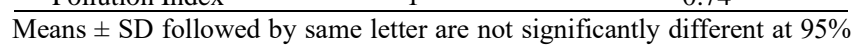
confidence level.

TABLE III: MEAN LEVELS OF ARSENIC IN EASTERN ZONE WATER BOREHOLES

\begin{tabular}{|c|c|c|}
\hline Borehole Codes & $\begin{array}{c}\text { Mean (mg/L) } \\
\pm \text { Standard Deviation } \\
\text { (Dry Season) } \\
\end{array}$ & $\begin{array}{c}\text { Mean }(\mathrm{mg} / \mathrm{L}) \\
\pm \text { Standard Deviation } \\
\text { (Wet Season) }\end{array}$ \\
\hline UE2 & $0.0229 \pm 0.0001^{\mathrm{a}}$ & $0.0031 \pm 0.0003^{\mathrm{r}}$ \\
\hline UE1 & $0.0141 \pm 0.0020^{\mathrm{a}}$ & $0.0076 \pm 0.0020^{\mathrm{p}}$ \\
\hline LE6 & $0.0137 \pm 0.0000^{\mathrm{a}}$ & $0.0024 \pm 0.0020^{t}$ \\
\hline LE1 & $0.0135 \pm 0.0000^{\mathrm{a}}$ & $0.0095 \pm 0.0000^{\mathrm{n}}$ \\
\hline LE2 & $0.0122 \pm 0.0010^{\mathrm{b}}$ & $0.0002 \pm 0.0002^{\mathrm{u}}$ \\
\hline LE8 & $0.0095 \pm 0.0000^{\mathrm{b}}$ & $0.0059 \pm 0.001^{\mathrm{q}}$ \\
\hline LE9 & $0.0095 \pm 0.0010^{\mathrm{b}}$ & $0.0099 \pm 0.0000^{\mathrm{n}}$ \\
\hline UE3 & $0.0082 \pm 0.0008^{c}$ & $0.0013 \pm 0.0002^{\mathrm{u}}$ \\
\hline LE4 & $0.0082 \pm 0.0000^{c}$ & $0.0013 \pm 0.0002^{\mathrm{u}}$ \\
\hline UE7 & $0.0080 \pm 0.0005^{\mathrm{c}}$ & $0.0072 \pm 0.0011^{\mathrm{pq}}$ \\
\hline LE3 & $0.0078 \pm 0.0000^{c}$ & Not detected \\
\hline LE5 & $0.0061 \pm 0.0000^{\mathrm{d}}$ & $0.0020 \pm 0.0010 \mathrm{t}^{\mathrm{u}}$ \\
\hline UE6 & $0.0061 \pm 0.0004^{\mathrm{d}}$ & $0.0040 \pm 0.0006^{\mathrm{r}}$ \\
\hline UE5 & $0.005 \pm 0.0015^{\mathrm{e}}$ & $0.0031 \pm 0.0005^{\mathrm{r}}$ \\
\hline LE7 & $0.0045 \pm 0.0001^{\mathrm{e}}$ & $0.0027 \pm 0.0000^{\mathrm{t}}$ \\
\hline UE4 & $0.0031 \pm 0.0003^{\mathrm{f}}$ & $0.0030 \pm 0.0007^{\mathrm{r}}$ \\
\hline UE9 & $0.0023 \pm 0.0002^{\mathrm{fg}}$ & $0.0030 \pm 0.0020^{\mathrm{r}}$ \\
\hline UE8 & $0.0020 \pm 0.0009^{g}$ & Not detected \\
\hline Overall Mean & $0.0087 \pm 0.0052$ & $0.0040 \pm 0.0022$ \\
\hline Calculated t-value & \multicolumn{2}{|c|}{3.57} \\
\hline $\begin{array}{l}\text { Critical t-value } \\
\text { (Tabled t-value) }\end{array}$ & \multicolumn{2}{|c|}{2.033} \\
\hline Contamination Factor & 0.8706 & 0.3976 \\
\hline Pollution Index & 0.8706 & 0.3976 \\
\hline
\end{tabular}

Means \pm SD followed by same letter are not significantly different at $95 \%$ confidence level.
TABLE IV: MEAN LEVELS OF ARSENIC IN NORTHERN ZONE WATER BOREHOLES

Mean (mg/L) Mean (mg/L)

Borehole Codes $\quad \pm$ Standard Deviation $\quad \pm$ Standard Deviation (Dry Season) (Wet Season)

\begin{tabular}{|c|c|c|}
\hline & (Dry Season) & (Wet Season) \\
\hline N7 & $0.0086 \pm 0.0002$ & $0.011 \pm 0.0000$ \\
\hline N1 & $0.0063 \pm 0.0005$ & $0.0025 \pm 0.0001$ \\
\hline $\mathrm{N} 3$ & $0.0049 \pm 0.0001$ & $0.0029 \pm 0.0001^{\mathrm{n}}$ \\
\hline N8 & $0.0048 \pm 0.0000^{\mathrm{a}}$ & $0.0027 \pm 0.0000^{\mathrm{n}}$ \\
\hline N5 & $0.0041 \pm 0.0002^{\mathrm{ab}}$ & $0.0024 \pm 0.0002$ \\
\hline $\mathrm{N} 2$ & $0.0033 \pm 0.0000^{\mathrm{b}}$ & $0.0019 \pm 0.0002$ \\
\hline N6 & $0.0023 \pm 0.000^{c}$ & Not detected \\
\hline $\mathrm{N} 4$ & $0.0021 \pm 0.0000^{\mathrm{c}}$ & $0.0009 \pm 0.0001^{\mathrm{p}}$ \\
\hline N10 & Not detected & Not detected \\
\hline N9 & Not detected & Not detected \\
\hline $\begin{array}{l}\text { Overall } \\
\text { Mean }\end{array}$ & $0.0046 \pm 0.0022$ & $0.0021 \pm 0.0008$ \\
\hline Calculated t-value & \multicolumn{2}{|c|}{3.09} \\
\hline $\begin{array}{l}\text { Critical t-value } \\
\text { (Tabled t-value) }\end{array}$ & \multicolumn{2}{|c|}{2.145} \\
\hline Contamination Factor & 0.455 & 0.2057 \\
\hline Pollution Index & 0.455 & 0.2057 \\
\hline
\end{tabular}

Means \pm SD followed by same letters are not significantly different at $95 \%$ confidence level.

TABLE V: MEAN LEVELS OF ARSENIC IN SOUTHERn ZONE WATER BOREHOLES

\begin{tabular}{|c|c|c|}
\hline \multicolumn{3}{|c|}{ BOREHOLES } \\
\hline Block Code & $\begin{array}{c}\text { Mean }(\mathrm{mg} / \mathrm{L}) \\
\pm \text { Standard Deviation } \\
\text { (Dry Season) }\end{array}$ & $\begin{array}{c}\text { Mean }(\mathrm{mg} / \mathrm{L}) \\
\pm \text { Standard Deviation } \\
\text { (Wet Season) }\end{array}$ \\
\hline S3 & $0.0142 \pm 0.0000$ & $0.0015 \pm 0.0000^{\mathrm{pq}}$ \\
\hline $\mathrm{S} 1$ & $0.0075 \pm 0.0001^{\mathrm{a}}$ & $0.0040 \pm 0.0000^{\mathrm{n}}$ \\
\hline $\mathrm{S} 12$ & $0.0071 \pm 00001^{\mathrm{a}}$ & $0.0030 \pm 0.0004^{\mathrm{np}}$ \\
\hline $\mathrm{S} 11$ & $0.0060 \pm 0.0010$ & $0.00295 \pm 0.0010$ \\
\hline S5 & $0.0055 \pm 0.0001$ & $0.0034 \pm 0.0004^{\mathrm{np}}$ \\
\hline S9 & $0.0044 \pm 0.0001^{\mathrm{b}}$ & $0.0026 \pm 0.0001^{\mathrm{np}}$ \\
\hline S8 & $0.0043 \pm 0.0 .0002^{\mathrm{b}}$ & $0.0025 \pm 0.0001^{\mathrm{np}}$ \\
\hline S10 & $0.0036 \pm 0.000^{\mathrm{bc}}$ & $0.0044 \pm 0.0001^{\mathrm{n}}$ \\
\hline $\mathrm{S} 2$ & $0.0025 \pm 0.0001^{\mathrm{cd}}$ & $0.0014 \pm 0.00013^{\mathrm{pq}}$ \\
\hline S6 & $0.0025 \pm 0.0001^{\mathrm{d}}$ & $0.0030 \pm 0.0004^{\mathrm{np}}$ \\
\hline S7 & $0.0020 \pm 0.00003$ & $0.0004 \pm 0.0000^{\mathrm{pq}}$ \\
\hline $\mathrm{S} 4$ & $0.0014 \pm 0.0000$ & $0.00097 \pm 0.0010$ \\
\hline $\mathrm{S} 13$ & Not detected & Not detected \\
\hline Overall Mean & $0.005083 \pm 0.0035$ & $0.0025 \pm 0.0012$ \\
\hline Calculated t-value & \multicolumn{2}{|c|}{2.45} \\
\hline $\begin{array}{l}\text { Critical t-value } \\
\text { (Tabled t-value) }\end{array}$ & \multicolumn{2}{|c|}{2.074} \\
\hline $\begin{array}{c}\text { Contamination } \\
\text { Factor }\end{array}$ & 0.5083 & 0.2507 \\
\hline Pollution Index & 0.5083 & 0.2507 \\
\hline
\end{tabular}

Means \pm SD followed by same letters down the column are not significantly different at $95 \%$.

TABLE VI: MEAN LEVELS OF ARSENIC IN WESTERn ZONE WATER BOREHOLES

\begin{tabular}{ccc}
\hline Block Code & $\begin{array}{c}\text { Mean }(\mathrm{mg} / \mathrm{L}) \pm \text { Standard } \\
\text { Deviation } \\
(\text { Dry Season) }\end{array}$ & $\begin{array}{c}\text { Mean }(\mathrm{mg} / \mathrm{L}) \\
\pm \text { Standard Deviation } \\
\text { (Wet Season) }\end{array}$ \\
\hline W6 & $0.0085 \pm 0.001 \mathrm{a}$ & $0.0025 \pm 0.0020 \mathrm{pq}$ \\
W2 & $0.0079 \pm 0.0000 \mathrm{a}$ & $0.0019 \pm 0.0010 \mathrm{qr}$ \\
W9 & $0.0063 \pm 0.0000 \mathrm{~b}$ & $0.0007 \pm 0.0003 \mathrm{r}$ \\
W3 & $0.0062 \pm 0.0011 \mathrm{~b}$ & $0.0037 \pm 0.0004 \mathrm{np}$ \\
W8 & $0.0054 \pm 0.0004 \mathrm{bc}$ & $0.0003 \pm 0.0000 \mathrm{np}$ \\
W4 & $0.0048 \pm 0.0012 \mathrm{c}$ & $0.0053 \pm 0.0040$ \\
W7 & $0.0045 \pm 0.0003 \mathrm{~cd}$ & $0.0039 \pm 0.0010 \mathrm{n}$ \\
W10 & $0.0041 \pm 0.000$ & $0.00131 \pm 0.0010$ \\
W11 & $0.0035 \pm 0.0000 \mathrm{de}$ & $0.0016 \pm 0.0010 \mathrm{qr}$ \\
W12 & $0.0026 \pm 0.001 \mathrm{e}$ & $0.0023 \pm 0.0000 \mathrm{q}$ \\
W5 & $0.0024 \pm 0.001 \mathrm{f}$ & $0.0022 \pm 0.0003 \mathrm{q}$ \\
W1 & $0.0001 \pm 0.001$ & $0.00226 \pm 0.0010$ \\
Overall Mean & $0.0047 \pm 0.0024$ & $0.0025 \pm 0.0012$ \\
Calculated t- & & \\
value & & \\
Critical t-value & & \\
(Tabled t-value) & & \\
Contamination & 0.4692 & 0.2524 \\
Factor & 0.4692 & 0.2524 \\
Pollution Index & & \\
\hline Means & &
\end{tabular}

Means \pm SD followed by same letters down the column are not significantly different at $95 \%$. 
As shown in Table II to VI, the study revealed that Central zone had a calculated t-value of 1.0 against a critical t-value (tabled t-value) of 2.101 at a significance level of 0.05 , indicating that the means of dry and wet seasons are not significantly different. On the other hand, the calculated tvalues for Eastern zone (3.57), Northern zone (3.09), Southern zone (2.42) and Western zone (2.81) were greater than the critical t- values of 2.033, 2.145, 2.074 and 2,074 respectively. This indicated that there was significant difference in the two seasons at a significance level of 0.05 for the four zones.

The contamination factor and pollution index are normally used to verify the level of contamination and pollution due to contamination effect from heavy metals. As shown in Table II to VI, the study revealed that the borehole waters during dry season were slightly contaminated for Central zone and very slightly contaminated for all the other zones. During the wet season, the contamination factor from the results showed that water from the different boreholes in all the five zones were very slightly contaminated with arsenic. The pollution index from the results showed that water from the different boreholes during both wet and dry seasons were not polluted with arsenic $(\mathrm{PI}<1)$.

\section{CONCLUSION}

The study revealed that arsenic concentration in water in some boreholes was above the WHO allowable limit for drinking water. However the boreholes were not contaminated. Arsenic in the borehole water should be regularly monitored in order to overcome health hazard due to arsenic accumulation.

\section{ACKNOWLEDGMENTS}

The authors thank the departments of Chemistry, Kenyatta University and Chemistry department, Jomo Kenya University of Science and Technology for the assistance during this study.

\section{REFERENCES}

[1] Nriagu JO, Bhattacharya P, Mukherjee AB, Bundschuh J, Zevenhoven $\mathrm{R}$, Loeppert RH, et al. Arsenic in Soil and Groundwater Environment [Internet]. 2007. $\quad$ p. 3-60. Available from:https://www.elsevier.com/books/arsenic-in-soil-andgroundwater-environment/bhattacharya/978-0-444-51820-0.

[2] Smedley PL, Kinniburgh DG. A review of the source, behaviour and distribution of arsenic in natural waters. Appl Geochemistry. 2002;17(2002):517-68.

[3] International Agency for Research on Cancer. Some Drinking-water Disinfectaants and Contaminants, including Arsenic [Internet]. http://monographs.iarc.fr/ENG/Publications. @who.int; 2004 [cited 2019 Mar 31]. Available https://www.ncbi.nlm.nih.gov/books/NBK402251/.

[4] WHO. Arsenic and Arsenic Compounds (Environmental Health Criteria) [Internet]. 2nd ed. Vol. 13. 2001. Available from: https://www.researchgate.net/publication/236154203_Arsenic_in_the _environment_-_An_overview_on_global_and_Sri_Lankan_context

[5] Jiang W, Hou Q, Yang Z, Zhong C, Zheng G, Yang Z, et al. Evaluation of potential effects of soil available phosphorus on soil arsenic availability and paddy rice inorganic arsenic content. Environ Pollution/ Sci Direct J. 2014;188:159-65.

[6] Zhu Y-G, Yoshinaga M, Zhao F-J, Rosen BP. Earth Abides Arsenic Biotransformations. Annu Rev Earth Planet Sci J. 2014;42(1):443-67.

[7] Ratnaike RN. Acute and chronic arsenic toxicity. Postgrad Med J.
2003;79:391-6.

[8] David SB, Hemond HF. Nitrate controls on iron and arsenic in an urban lake. Science (80- ). 2002;(296):2373-2376.

[9] George CM, Sima L, Helena M, Arias J, Mihalic J, Cabrera LZ, et al. Arsenic exposure in drinking water : an unrecognized health threat in Peru [Internet]. Vol. 92, Bull World Health Organ. 2014. p. 565-72. Available from:https://doi.org/http://dx.doi.org/10.2471/BLT.13.128496.

[10] Yunus F, Khan S, Chowdhury P, Milton AH. A Review of Groundwater Arsenic Contamination in Bangladesh : The Millennium Development Goal Era and Beyond. Int J Environ Res Public Health. 2016;13(2):215.

[11] Shibata T, Meng C, Umoren J, West H. Risk Assessment of Arsenic in Rice Cereal and Other Dietary Sources for Infants and Toddlers in the U.S. Int J Environ Res Public Heal. 2016;13(4):361.

[12] Sen G. Cooperation Between India and Bangladesh on Control of Arsenic Poisoning [Internet]. Institute for Defense studies and analyses. 2013 [cited 2019 Mar 24]. Available from: https://idsa.in/idsacomments/CooperationBetweenIndiaandBanglades h_GautamSen_270113.

[13] Mukherjee A, Das B, Rahman MM, Chakraborti D. Arsenic Contamination in Groundwater: A Global Perspective with Emphasis Arsenic Contamination in Groundwater: A Global Perspective with Emphasis on the Asian Scenario. J Heal Popul Nutr. 2006;24(2):14263.

[14] Ahamed S, Sengupta MK, Mukherjee SC, Hossain MA, Das B, Nayak B, et al. An Eight-year Study Report on Arsenic Contamination in Groundwater and Health Effects in Eruani Village, Bangladesh and an Approach for Its Mitigation [Internet]. Vol. 24. 2006. Available from: www.bioline.org.br/pdf?hn06019.

[15] van Halem D, Bakker SA, Amy GL, Dijk JC Van. Arsenic in drinking water : a worldwide water quality concern for water supply companies. Drink Water Eng Sci J. 2009;2:29-34.

[16] Nwoke IB, Edori ES. Concentration of Heavy Metals in Borehole Water from Ikono. Int J Adv Res Chem Sci. 2020;7(1):27-33.

[17] Rahman A, Persson L-åke, Nermell B, Arifeen S El, Ekström C, Smith $\mathrm{AH}$, et al. Exposure and Risk of Spontaneous Abortion, Stillbirth , and Infant Mortality. Epidemiology. 2010;21(6):797-804.

[18] Chen AY-Y, Olsen T. Chromated copper arsenate - treated wood : a potential source of arsenic exposure and toxicity in dermatology. Int J Women's Dermatology. 2016;2(1):28-30.

[19] Chakrabarti D. Arsenic: Occurrence in Groundwater Arsenic: Occurrence in Groundwater in. In: Encyclopedia of Environmental Health [Internet]. 2nd ed. Elsevier Inc.; 2018. p. 1-16. Available from: http://dx.doi.org/10.1016/B978-0-12-409548-9.10634-7.

[20] WHO. Arsenic [Internet]. World Health Organization. 2018 [cited 2019 Apr 1]. Available from: https://www.who.int/news-room/factsheets/detail/arsenic.

[21] National Environment Management Authority (NEMA) Environmental Management And Co-Ordination (Water Quality) Regulations, 2006 [Internet]. Legal Notice number 120 Kenya: National Environment Management Authority (NEMA); 2006 p. $1-$ 25. Available from: https://www.betacare.co.ke/.../Water Quality Regulations ken84962.pdf\%0A.

[22] Kenya National Bureau of Statistics. 2019 Kenya Population and Housing Census - Vol. 1 [Internet]. 2019 [cited 2020 Oct 25]. p. 8. Available from: https://www.theelephant.info/documents/2019kenya-population-and-housing-census-vol-1/.

[23] Thiongo J. Hope for Nairobi residents as Government drills bore holes. Standard Digital News [Internet]. 2017 Apr 5; Available from: https://www.standardmedia.co.ke/article/2001235135/hope-fornairobi-residents-as-government-drills-bore-holes.

[24] US-EPA. National Primary Drinking Water Regulations; Arsenic and Clarifications to Compliance and New Source Contaminants Monitoring [Internet]. The Daily Journal of the United States $\begin{array}{llll}\text { Government. } & 2001 . & \text { Available } & \text { from: }\end{array}$ https://www.federalregister.gov/documents/2001/01/22/011668/national-primary-drinking-water-regulations-arsenic-andclarifications-to-compliance-and-new-source.

[25] Makokha AO, Kinyanjui PK, Magoha HS, Mghweno LR, Nakajugo A, Wekesa JM. Arsenic Levels in the Environment and Foods Around Kisumu , Kenya. Open Enviromental Eng J. 2012;5:119-24.

[26] Weinber C. Arsenic and Drinking Water. LWW J. 2004;15(2):255.

[27] Open-Africa. Boreholes in Nairobi County [Internet]. 2015. Available from: https://africaopendata.org/dataset/66145814-0933-439b-9027fa02b2636682/resource/99a950a7-ffb1-416d-a801498e3f2d1d48/download/boreholes-in-nairobi-county-2015.xlsx

[28] Etyang FO, Muse GS. Concentrations of Selected Trace Elements and their Temporal Variation in Borehole Water, Eldoret Municipality, Kenya. Int J Environ Chem Ecotoxicol Res. 2016;1(2):1-10. 
[29] Iqbal F, Raza N, Ali M, Athar M. Contamination of Kallar Kahar Lake by Inorganic Elements and Heavy Metals and their Temporal Variations. J Appl Sci Environ Manag. 2006;10(2):95-8.

[30] Al-Weher SM. Levels of heavy metal $\mathrm{Cd}, \mathrm{Cu}$, and $\mathrm{Zn}$ in three fish species collected from the Northern Jordan Valley, Jordan. Jordan J Biol Sci. 2008;1(1):41-6.

[31] Mugenda OM, Mugenda AG. Research Methods Quantative and Qualitative Approaches. 2003rd ed. Nairobi: Acts Press; 2003.

[32] Verma P, Singh KP, Tiwari AK, Sharma S, Purty P. Review of Various Contamination Index Approaches to Evaluate Groundwater Quality with Geographic Information System ( GIS ). Int J ChemTech Res. 2015;7(4):1920-9.

[33] Srinivas P, Kumar P, Srinivatas GN, Prasad A, Hemalatha T. Generation of Groundwater Quality Index Map- A case study. Civ Environ Res. 2011;1(2):9-21.

[34] Caliman AF, Robu MB, Smaranda C, Pavel L V, Gavrilescu M. Soil and groundwater cleanup: benefits and limits of emerging technologies. Clean Techn Environ Policy. 2011;13(2):241-268.

[35] Lacatusu R. Appraising levels of soil contamination and pollution with heavy metals. Eur Soil Bur Res. 2000;4:393-402.

[36] Muraguri PM. Assessment of Groundwater Quality in Nairobi County, Kenya. Jomo Kenyatta University of Agriculture and Technology; 2013 . 